\title{
How is Reasoning Ability in Learning Real Analysis?
}

\author{
Isnani Isnani* \\ Department of Mathematics Education \\ Universitas Pancasakti Tegal \\ Tegal, Indonesia \\ *isnani.ups@gmail.com
}

\author{
Stevanus Budi Waluya, Rochmad Rochmad, \\ Sukestiyarno Sukestiyarno, Amin Suyitno \\ Department of Mathematics Education \\ Universitas Negeri Semarang \\ Semarang, Indonesia \\ amin.mat@mail.unnes.ac.id
}

\author{
Neneng Aminah \\ Department of Mathematics Education \\ Universitas Swadaya Gunung Jati \\ Cirebon, Indonesia \\ nenengaminah255@gmail.com
}

\begin{abstract}
Each Mathematics Education students take Real Analysis subject must have reasoning ability. However most of them have a low reasoning ability. Reasoning ability is a drawing conclusion process by linking facts in problem solving which includes deductive thinking. The reasoning ability is able to explore their ideas and knowledge in Real Analysis subject. This research aims to describe students' reasoning ability achievement in Real Analysis subject. This research uses qualitative data. The subjects of the research are students who take the Real Analysis subject chosen by using purposive sampling. The research result reveals most of the students answer incorrectly in solving Real Analysis questions which the error is a common mistake, however the other mistakes such as misconception, careless, or just write the question are also revealed in this research.
\end{abstract}

Keywords: reasoning ability, Real Analysis, deductive thinking

\section{INTRODUCTION}

Reasoning ability is required by the students who study mathematics. Moreover, as the students in Mathematics Education Program, they must have a good reasoning ability. This ability is the important aspect in learning mathematics because the mind-set which is developed in mathematics requires and involves critical thinking, systematic, logic, and creative. Therefore, mathematics education students must have a good reasoning ability to study mathematics easier. The reasoning ability is very important in making estimation on the basis of experience so that they are going to get concept understanding and meaningful learning [1].

The definition of reasoning according to NCTM [2] is a conclusion drawing process based on Conclusion process based on evidence and assumptions. The reasoning underlies mathematics, so it is part of the scientific discipline [2]. As well, mathematical reasoning is the reasoning about mathematical explanation and the objects involved in mathematics [1].

According to Barrody [1] Mathematical reasoning is divided into intuitive reasoning, inductive reasoning, and deductive reasoning. Whereas for intuitive reasoning underlies a conclusion of things which look or feel right (assumptions), inductive reasoning is began with examine some events and then draw a general conclusion, and deductive reasoning is began with a premise is used to conclude certain events. NCTM [2] states that mathematical reasoning is understood to cover formal reasoning, or evidence where compatibility is logically deduced from assumptions and definitions. McGraw [3] also stated that besides deductive and inductive reasoning, there is a transformational reasoning which involves visualization action mentally and the result of the action [3]. From another point of view, there are two kinds of reasoning, creative reasoning and imitative reasoning [4]. Based on experts' opinion above, there are five categories of reasoning, inductive reasoning, deductive reasoning, transformational reasoning, creative reasoning and imitative reasoning.

This research uses deductive reasoning which are a process of conclude the common evidences to particular evidences. While, Agapay stated that deductive reasoning is a process towards a particular truth which is built from a general truth [5]. There are three steps on the process of drawing conclusion deductively: make a general statement which referring to whole the set or objects classification, make a particular statement about one or some the set members or classification that refers to general statements, and make the deduction is done logically when the general statements applied in the particular statements [6].

A deductive reasoning of students based on their ability to solve a mathematics problem. The students are able to develop and build new ideas from knowledge already owned, they also are going to get an experience of using knowledge and skill already owned to be applied on solving problems that are not routine through mathematical problem solving activities. This problem can be categorized into two types, problem of find and problem of proof.

This mathematical verification ability is important not only to train students' thinking ability, but also to find out their flow of mathematical thinking and to take a part of developing 
mathematics as a science-discipline. The comprehension and the good mathematic basic concepts are needed in achieving the mathematics verification ability. Some research indicate that some students can write proof only at some level of verification. The research result from Van Dormolen defined that there are three levels of verification, such as ground level, first level, and second level [7]. Likewise other similar research results defined that verification level: naïve empiricism, crucial experiment, generic example, and thought experiment. [8-10].

Vanspronsen stated that the proof is a series of premises are known later with rules of inference towards a conclusion. So, mathematical proof construction is a mathematic assignments where students are provided with some preliminary information (assumptions, axioms, definitions) and asked to apply rules of inference (using previous facts, applying theorem) until a conclusion truly expected is obtained [11].

The research result from Moore [12], defined that there are seven errors in mathematical verification such as:

- The students do not know the definition and they cannot state the definition,

- The students have a little intuitive understanding from the concept

- The students' concept image is inadequate to do a prove,

- The students cannot and do not want to build and use their own example,

- The students do not know how to use the definition to determine the whole prove structure,

- The students are not able to understand and use the language and the notation of mathematics, and

- The students do not how to begin with the proof.

In addition, Moore stated that the students' difficulties to prove something because of the lack of knowledge of material content [12]. Sometimes, the students understand about the definition and can explain it informally but they cannot state the definition to prove the proof. Moore also defined that the source of the difficulty is caused by three aspects such as, concept understanding (definitions, images and uses), the lack of logic knowledge and prove method, and also the limitations of language and notation. The students also more focus on the procedures than content. Furthermore, the students realize that they like to memorize the proof since they do not understand what proof is and how to explain it [11]. Likewise the research result of Perbowo and Pradipta [13] was obtained that the students find it difficult to prove in mathematics and the same errors was obtained as found in Moore [12].

Some of mathematics education students assume Real Analysis subject as the hardest subject than the other subjects because Real Analysis subject is the first subject for the students to practice their reasoning and prove mathematic statements formally. This subject equip the students the reasoning ability which is one of mathematic competences [1417]. Then, the students' reasoning ability can be grown through Real Analysis subject with deductive thinking. According to
Bartle and Sherbert [18,19], Real Analysis is very needed to solve problems, develop deductive thinking ability, analyse mathematical situation from other science such as economics and management, engineering, physics, and computer science $[18,19]$.

Based on the analysis above, this research aims to describe the student's errors in solving Real Analysis problems and describe how to resolve the students' difficulties in learning Real Analysis subject.

\section{RESEARCH METHODOLOGY}

This research uses qualitative approach. The subject of this research is students who take Real Analysis subject in Mathematics Education Program Universitas Pancasakti Tegal Indonesia Academic Year 2018/2019, which are chosen using purposive sampling. The data source which is used for the research analysis divided into two categories, such as: (1) the respondent test results of Real Analysis subject, and (2) respondents source, chosen using purposive sampling, which is based on criteria: have an important role in learning Real Analysis, have a valuable knowledge appropriate with the research study, and have the desire to cooperate and share an information about the research study. Variable used in this research is mathematical reasoning ability.

After conducting the data, analysis is done by juxtapose the data findings according to the theoretical basis from the Moore [12] research and the findings of this research, such as:

- Identify the errors in solving Real Analysis test.

- Identify mathematical reasoning ability and the effort to improve students' mathematical reasoning abilities.

- Draw a conclusion.

Qualitative data process is based on reasoning ability category criteria, while the category of reasoning ability achievement can be seen on table 1:

TABLE I. REASONING ABILITY CATEGORY

\begin{tabular}{|l|l|l|}
\hline No & \multicolumn{1}{|c|}{ Score } & \multicolumn{1}{c|}{ Achievement Level } \\
\hline 1 & $85 \leq s \leq 100$ & Very good \\
\hline 2 & $65 \leq s<85$ & Good \\
\hline 3 & $50 \leq s<65$ & Enough \\
\hline 4 & $25 \leq s<50$ & Bad \\
\hline 5 & $0 \leq s<25$ & Very bad \\
\hline
\end{tabular}

\section{RESEARCH FINDINGS AND DISCUSSION}

Based on the research findings, the following results will be discussed as follows:

\section{A. The Analysis Results of the Error and its Causes on Real Analysis Problems Solving}

The questions used to find out the errors and its causes in solving Real Analysis problems are the essay-form questions. 
Based on the research results, ten errors students always do in solving Real Analysis questions consist of seven errors which was already obtained from Moore [12], and the three others are the errors was obtained from this research. The achievement levels of the seven similar errors from Moore [12], such as:

- 48 students do not know the definition and they cannot state the definition,

- 39 students have a little intuitive understanding from the concept,

- 45 students' concept image is inadequate to do a prove,

- 42 students cannot and do not want to build and use their own example,

- 18 students do not know how to use the definition to determine the whole prove structure,

- 54 students are not able to understand and use the language and the notation of mathematics, and

- 38 students do not how to begin with the proof.

In addition, there are other errors and its causes in solving Real Analysis problems in this research such as:

- The students are misconception with achievement,

- Careless students, and

- Students who just write the questions.

Based on the errors above, the research findings have similar causes with Moore [12], and also there are additional findings such as:

- the students are misconception because they solve the problems without using the right concepts or principles as Valverde and Castro [20] stated that students fail in interpreting axioms so that they misplace axioms which are used, it caused the failure of systematic problem solving,

- The students are careless because they are less thorough in reading the questions or cannot manage the time so that they feel hurry [20]. As stated Kuhn and Franklin [21]; Boudreaux et al. [22], the students cannot identify the questions because of the lack of solving deductive reasoning questions exercises so that they cannot interpret the problem well,

- The students simply write the questions. The causes can be various. It can be the questions are very difficult for the students because of heterogeneous student input.

\section{B. Analysis of Reasoning Ability Enhancement}

Based on the average results above we can conclude that the reasoning ability of Mathematics Education Bachelor Program Universitas Pancasakti Tegal Indonesia need to be grown. The reasoning exercises both formally and informally are given to the students to foster students' reasoning. According to Boesen et al. the students are able to develop and increase their reasoning ability with the frequent deductive reasoning exercises [23]. In addition, Woolley et al. stated that the students will grow their natural reasoning by giving these exercises, moreover heterogeneous student conditions provoke the students' different mind-sets and will definitely improve students' reasoning abilities [24]. The students should not be forced to use the same pattern to grow their reasoning ability because of their heterogeneous conditions. In case this situation happens then this problem solving of deductive reasoning will be fail [25-27]. Then, Boesen et al. stated that the giving of deductive reasoning exercises can use the book besides the usual handbook so that the students are accustomed on solving new problems [23].

\section{CONCLUSION AND SUGGESTION}

Based on the research findings, there are ten errors which students done in solving Real Analysis questions, with details: seven errors are similar with the errors which were discovered in the Moore [12] research findings and three errors are discovered in this research, such as misconception, careless, and just write the question. The student's condition which is used in this research were very heterogeneous.

The students have to practice in solving the deductive reasoning ability questions from the lowest type of question to the highest type of question continuously.

\section{REFERENCES}

[1] A.J. Barrody, Problem Solving Reasoning, and Comunicating, K-8 Helping Children Think Mathematically, New York: Macmillan Publishing Company, 1993

[2] NCTM, Principles and Standards for School Mathematics, Reston: The National Council of Teachers of Mathematics, Inc., 2000.

[3] R. McGraw and E. Rubinstein-Ávila, "Middle school immigrant students developing mathematical reasoning in Spanish and English," Bilingual Research Journal, vol. 31, no. 1-2, pp. 147-173, 2009.

[4] J. Lithner, "Principles for designing mathematical tasks that enhance imitative and creative reasoning," Zdm, vol. 49, no. 6, pp. 937-949, 2017.

[5] RB. Agapay, Logic The Essentials of Deductive Reasoning, Quezon City: National Book Store, 1991

[6] B. Rich and C. Thomas, Schaum's outlines Problem Solved. Geometry fourth Editioan, New York: The McGraw-Hill Companies Inc., 2009.

[7] J. Van Dormolen, "Learning to understand what giving a proof really means," Educational Studies in Mathematics, vol. 8, pp. 27-34, 1977.

[8] E. Knuth, "Secondary school mathematics teachers' conception of proof," Journal for Research in Mathematics Education, vol. 33, no. 5 , pp. 379- 405, 2002.

[9] W.G. Martin and G. Harel, "Proof frames of preservice elementary teachers," Journal for Research in Mathematics Education, vol. 20, no. 1 , pp. $41-51,1989$.

[10] D. Almeida, "Engendering proof attitudes: Can the genesis of mathematical knowledge teach us anything?," International Journal of Mathematical Education in Science and Technology, vol. 34, no. 4, pp. 479-488, 2003.

[11] H.D. Vanspronsen, Proof Processes Of Novice Mathematics Proof Writers (Dissertation), Missoula: University of Montana, 2008.

[12] R.C. Moore, "Making Transition to Formal Proof," Journal of Educational Studies in Mathematics vol. 27, pp. 249-266, 1994.

[13] K.S. Perbowo and T.R. Pradipta, "Pemetaan Kemampuan Pembuktian Matematis Sebagai Prasyarat Mata Kuliah Analisis Real Mahasiswa Pendidikan Matematika," Kalamatika: Jurnal Pendidikan Matematika, vol. 2 , no. 1, pp. 81-90, 2017. 
[14] K.E. Lestari, “Analisis kemampuan pembuktian matematis mahasiswa menggunakan pendekatan induktif-deduktif pada mata kuliah analisis real," MENDIDIK: Jurnal Kajian Pendidikan dan Pengajaran, vol. 1, no. 2, pp. 28-135, 2015.

[15] M. Syawahid, "Kemampuan berfikir formal mahasiswa," Beta: Jurnal Tadris Matematika, vol. 8, no. 2, pp. 125-141, 2015.

[16] A. Septian, "Pengaruh Kemampuan Prasyarat terhadap Kemampuan Penalaran Matematis Mahasiswa dalam Matakuliah Analisis Real,' ATIKAN, vol. 4, no. 2, 2014.

[17] L. Sucipto and M. Mauliddin, "Analisis kesulitan belajar mahasiswa dalam memahami konsep bilangan real," Beta: Jurnal Tadris Matematika, vol. 9, no. 2, pp. 197-211, 2016.

[18] R.G. Bartle and D.R. Sherbert, Introduction to Real Analysis - 3th Edition, New York: John Wiley \& Sons, 2000.

[19] R.G. Bartle and D.R. Sherbert, Introduction to Real Analysis - 4th Edition, Illinois: John Wiley \& Sons, 2011

[20] G. Valverde and E. Castro, "Prospective elementary school teachers' proportional reasoning," PNA, vol. 7, pp. 1, 2012.

[21] D. Kuhn and S. Franklin, The second decade: What develops (and how). In (6th ed.), Handbook of child psychology, Hoboken, NJ: John Wiley \& Sons, 2006
[22] A. Boudreaux, P.S. Shaffer, P.R. Heron, and L.C. Mcdermott, "Student understanding of control of variables: deciding whether or not a variable influences the behavior of a system," American Journal of Physics, vol. 76, pp. 163-170, 2008.

[23] J. Boesen, J. Lithner, and T. Palm, "The relation between types of assessment tasks and the mathematical reasoning students use," Educational studies in mathematics, vol. 75, no. 1, pp. 89-105, 2010.

[24] J.S. Woolley, A.M. Deal, J. Green, F. Hathenbruck, S.A. Kurtz, T.K Park, and J.L. Jensen, "Undergraduate students demonstrate common false scientific reasoning strategies," Thinking Skills and Creativity, vol. 27, pp. 101-113, 2018.

[25] M.S. Cracolice and B.D. Busby, "Preparation for college general chemistry: More than just a matter of content knowledge acquisition," Journal of Chemical Education, vol. 92, no. 11, pp. 1790-1791, 2015.

[26] A. Hilton and G. Hilton, "Proportional reasoning: An essential component of scientific understanding," Teaching Science, vol. 62, no. 4, pp. 32, 2016.

[27] L. Ding, X. Wei, and K. Mollohan, "Does higher education improve student scientific reasoning skills?," International Journal of Science and Math Education, vol. 14, pp. 619-634, 2016. 